\title{
Future past I am a coolie-al... and I reside as an invisible island inside the ocean: Tidalectics, transoceanic crossings, coolitude and a Tamil identity
}

\author{
Yaso Nadarajah \\ School of Global, Urban and Social Studies, RMIT University, Australia \\ yaso.nadarajah@rmit.edu.au
}

\begin{abstract}
The politics of Tamil working-class identity in Malaysia continue to be articulated in subaltern terms, employing term such as 'coolie', which is elsewhere an archaic usage from colonial days. Yet the power of the coolie narrative appears salient, and the coolie odyssey is far from over. Drawing upon the author's longitudinal work with a Tamil squatter settlement in the heart of the city of Kuala Lumpur in the Malay Archipelago, this paper moves from third to first and then second narrative to capture the broad range of ruptures and transformations of Tamil sensibilities, a 'coolitude' that grew a pattern of life which emerged from a journey that began on the sea. In this article, the author envisions the 'black ocean' as an invisible island; shaped by colonial and imperial histories, racial capitalism and ocean crossings. These transoceanic crossings carried the weight of Tamil histories, rooted in the seas as an invisible island - as both the rupture of an identity and a translation from western namings and discourses. What remains is the 'island', rooted in the seas as a colonial wound of history, a tidalectic between transoceanic migration, personhood and language. This community is more than just its resilience, its assertions of power, its affair with identity and belonging, and its response to deep social inequalities in its homeland. It is also a space of a poetics of resoluteness to recover an identity that is not fractured, not alienated from place and transoceanic crossings. This paper attempts a retelling of a hidden hyphen that held the labourer and the personhood apart, but also together. It navigates through the concept of tidalectics first postulated by Barbadian poet and historian Kamau Braithwaite (2003) in conjunction with Valentine Daniel's (2008) The Coolie and Khal Torabully's (1992) Coolitude. The paper seeks to understand more deeply the performativity of the hyphen as an invisible island inside the ocean.
\end{abstract}

Keywords: coolitude, indentured labour, islands, narrative, performativity, tidalectics, transoceanic crossings

https://doi.org/10.24043/isj.159 • Received May 2020, accepted March 2021

(C) Island Studies Journal, 2021 


\section{The third narrative}

And now, there was for Kannamma, a-once-rubber tapper, this problem of what will happen to the mango tree now growing in this squatter settlement. It had come from the seed her grandmother has planted in the rubber plantation; where she, Kannamma, too had lived; growing up, tapping rubber, as a young girl, 40 years ago.

What will I do with this mango tree?, asked Kannamma, in Tamil. My grandmother ate the mangos from her village (sontha ur) she stored in her bag while crossing the ocean (kadal) and brought the seeds with her to this country. My mother was just two years old then-and these mangoes were her food. My grandmother planted the seeds when they were finally brought to this estate (rubber plantation) in Batang Berjuntai. My mother grew up eating the fruits and when she had to leave the estate which was closed, she brought a couple of the seeds here. And planted them outside her hut 40 years ago. She is dead and gone-but her tree is alive. Now we must move to this new place because they (government officials) are going to demolish all these huts. What will I do? What will I do? What will happen to our tree?

She started wailing; and the other women began to comfort her. I felt awkward, an outsider; trying to understand the pain of separation from a tree. Suddenly she stopped wailing; and looked at me. You come here and have talked with us for a while now. You are Tamil like us; but not still a coolie-al (coolie person) like us. You know what we mean? Did I?

I know what I will do, Kannamma said. She went towards the tree and pulled out a sapling growing by its side. Here, you take this and plant it in memory of my grandmother-and the sea she crossed to bring us here. Nobody remembers us-and you remember us for us.

It is a story of losing one's history and identity, looking desperately for them and then, trying to recreate them with the resources available.

I held the sapling in my hands. Where will I plant this, I asked? I don't know; she said. But please don't let it die. The taxi took me back to the hotel where I stay during fieldwork, the sapling carefully bundled in my hands. That night I called my mother who lives in another town $200 \mathrm{kms}$ away. I told her what had happened. She was silent for a while; and then said; bring it here. We will plant the mango sapling in the garden here; her 'kala pani' is also ours, in many ways. My grandparents had also to migrate to Malaya during colonial rule - my grandfather to become one of the administrators of the railway system in British Malaya. Till his death, he spoke of his travel across the Indian Ocean to Malaya (now Malaysia) as a journey across dark waters to a land that never became his own.

If I were to seek out the one bond that bound these older women I was conversing with, in this squatter settlement called Kampung (Village) Gandhi in the middle of Kuala Lumpur city in Malaysia, the one that would become visible repeatedly was this journey by sea, from their villages in India. This bond was strong in them, wrought across the ocean, intact in the stories their grandmothers brought with them as they crossed the ocean. This land/sea relationship appeared to remain both a uniting and a separating memory-these women continuing to lament a rupture from a land (India) that their families left long before. Why does the ocean remain entrenched in their stories-why does the journey across the ocean still play a part in these narratives?

I was confronted by this word thrown at me- 'coolie-al'-as if in a mixture of defiance and pride. Why did this lady and her friends use this term to describe themselves; when it seemed that most of us in the modern world have relegated it to the relics of the colonial empire? Over several visits, I ventured to ask them about the word 'coolie' and what that meant to them. Within the Malaysian context, 'coolie' is a highly pejorative term and was 
widely employed throughout colonial era to collectively and individually describe low-paid contractual labourers of all ethnic backgrounds. The use of the term has been officially discouraged since Merdeka (Independence in 1957), and indeed is regarded as insulting and disparaging.

Yet what emerged from such discussions and conversations with many members of this squatter settlement over a period of more than ten years was of a people constructing and negotiating the limits of their lives, beliefs and practices (within a rapidly modernising, yet marginalising environment) from the historical experiences of their ancestors through oral stories and sources. For many of those people I met, the term 'coolie' was both a painful reminder of the journey from their ancestral land; but also, a proud label for their hard work that had built a nation. Some of the men who joined the conversations seated around the dilapidated coffee shed at the border of Kampung Gandhi and Kampung Nehru became quite strident as they spoke of their fathers and mothers, who had worked hard in the rubber plantations. I was reminded of this poem written by Somachanda in 1930, from an edited collection of poems (Haridas \& Dhandayudham, 1981) entitled The Interior Landscape of the Heart. The pejorative, colonial notion of the 'coolie' invoked by these women and men in the settlement and also in Somachanda's poem was not only a mark of identity and pride, but also a trajectory of their work and their life.

\section{A Tapper Rejoices}

From the moment I wake, I look

For my carrying stick

The coffee I drink

Fills a quarter of my belly

If I am to work

I must attend roll call

I run all the way

Without even looking at the house

My chisel must be sharp

Enough to cut four hundred trees

I push my way through the undergrowth

All day long

I must tap carefully

Without wounding the trees

I tap and kneel and stand

And spin from tree to tree

By ten, the latex must be ready

I bow to the boss when he comes

Then carry the rubber to the store

Where I sit, holding my hips 
I must take the price I'm given

Clean my chisel and wash my bucket

If it rains, I sat at home

It's hard to satisfy a family this way

We are the base of the economy

We are poor, but rejoice in this

We have suffered, but are proud

Of what we have achieved with our hands

Somachanda, 1930

\section{Uprootedness, coloniality, pain and pride}

This paper begins by drawing upon my longitudinal work (Nadarajah, 2007a; Nadarajah, 2007b) with a Tamil squatter settlement in the heart of the city of Kuala Lumpur in the Malay Archipelago. The paper moves from third to first and then second narrative, drawing on the narratives from members of this working-class Tamil community settlement; whilst also weaving the term 'coolitude' (Torabully, 1992) - a journey that best captures the wide range of ruptures and transformations of such Tamil communities' sensibilities. It attempts to draw a pattern of life, which emerged from the journey that began on the sea, and connects to Kamau Braithwaite's terminology of tidalectics, which facilitates a reterritorialization of postcolonial historiography. In this, I also attempt to capture the performativity of a complex sensibility, rooted in the sea as an invisible island. The process of the paper is a reflexive encounter with the ontological and epistemological journey of the term 'coolie'; and the way it is contesting, negotiating and constituting its own transoceanic connection to its identity.

To begin with, my reason to be here, at this squatter settlement, was part of a large local-global study of the notion of 'community', especially for those most affected or marginalised by development and state-led planning. The idea of community has been growing in popularity. Work by Delanty (2003) and Rose (2008); as well my own research (Mulligan \& Nadarajah, 2008; Glen et al, 2011) attests to a notion that there has been in fact a turn to community in the face of increasing global flux and uncertainty. According to Delanty's (2003) account, communities can only exist if they are wilfully constructed; and this idea has exerted itself as a powerful idea of belonging in every age. But increasingly, as my intellectual biography becomes tied up with these questions around community and what that might mean in places like this squatter settlement, my journey has become far more complicated. The word 'community' does not decode in the same sense in the Tamil vocabulary. Words associated with or closest to this term 'community' translate as 'a part of', 'caste, society, or neighbourhood', or 'place or village or country'. Perhaps the word 'community' is overused in the English language because old conceptions of belonging have been abandoned in the rush towards modernity. Of course, the position of this Indian community cannot be meaningfully interrogated without reference to the politico-cultural discourses within Malaysia itself, dominated by contestation surrounding ethnic identity, religion, education and language.

I recognise that the complex uncertainties faced by these working-class Tamils located within these squatter areas in this Kuala Lumpur section are also fuelled by large macropolitical landscape transformations, which, in turn, are driven by the ethno-racial discourses of the 
developmental state and private capital. These topics are vast; and the work of scholars like Wilford (2008, 2006, 2002); Vadivelu (2015); Ramasamy P. (2006, 2000, 1992); Pillai (2008, 2007, 2004); Professor Arasaratnam (1993) amongst others provide much comprehensive and critical insight into the plight of the Tamils in Malaya (and now Malaysia).

My critical focus in this paper is to map the politics of displacement and the framing of this term 'coolie', and the way it has emerged; framing both the impetus and the rhetorical force of the coolie riots in 1941 and the Hindu Rights Action Force (HINDRAF) Rally in 2007. This intersection of political frustration and anxiety that had mobilized the Tamil community also opens the question of the word 'coolie' itself. Daniel $(2001,1992,1981)$ provides valuable insightful analysis into the idea of 'Tamil'- and opens the idea of being a person the Tamil way. But it was coming into Khal Torabully's work on the torturous journey by sea by indentured labourers, which he termed 'coolitude', and the field of island studies (Grydehøj, 2017; Nadarajah \& Grydehøj, 2016) that I found the ocean. The ocean, and the memories that this Tamil community carried within them, showed a resoluteness to hold onto an identity fractured, but not alienated from, its transoceanic crossings.

Some of these constructions that historically constitute the notion of a 'coolie' in the matrix of power relations make the term 'coolie' is difficult to grasp, especially as so little has been written about the everyday lived realities of these indentured labourers. As Breman and Daniel (1992, p. 268) attest:

The identity of a labourer as a coolie, like the identity of anything or anybody, is complexly constituted and however exhaustively described, will remain only partially defined. Coolie identity is as much the product of self-perception as it is the construction of a category by those who did not belong to it.

Much of what has been written about the 'coolie' is the product of the second category, of those who stand outside it. And in every way, I too am an outsider, further distanced by the fact that I now live overseas; where the word 'coolie' exists only as a relic of the colonial empire. The plantation economy, 'home' to the coolies, was one of colonial capitalism's most productive enterprises of the $19^{\text {th }}$ and first half of the $20^{\text {th }}$ Centuries. Many plantations today remain empty and in ruins - as the government decides what best to do with these vast acres of overgrown trees and decaying buildings. More recently, several plantations are being restored and are called 'tea gardens' in tourist brochures. But if, like Daniel (1992), one views them as 'imperial debris', then these tea gardens take on a whole new meaning. And they then also become laden with a history - rich in one instance and destitute in the otherforming, often, an irreconcilable complementarity.

Malaya was one of those spaces within the protectorate of the imperial governance of England where colonists built upon codes of conduct that ensured their exclusive governing space; and colonialist literature on Malaya reveals much of this rule. But at the same time, forms of resistance, ranging from individual acts to more conspicuous acts of desertion or collective resistance (Ramasamy, 2006; Ramasamy, 1992; Pillai, 2007; Pillai, 2008) were not uncommon, and many were forcibly put down. As Cooper and Stoler (1997) claim, despite the tight rites of governance that were exercised, many labourers were capable of circumventing and undermining the practices of capitalist and economic domination. Many too would argue that the notion of the Indian as a docile coolie began to diminish during the 
formative experiences of the Japanese occupation, when the Indian National Army and the Indian Independence League instilled notions of independence and pride. Many Indians in Malaya themselves became involved in the Indian nationalist struggle for independence against the fading might of the British Empire.

What had these settlers left behind in the oceans as they came ashore? The ocean journey, for many seen as a crossing of the kala pani or black water, disrupted lifeworlds of caste and kinship systems, rituals and belonging. The word kala pani, coined possibly in the $19^{\text {th }}$ Century (Mohammad, 2002), captured the loss these migrants experienced as they left or were forced to leave the Indian Subcontinent. For many here, like those in the settlement in Kuala Lumpur, the loss remains rooted in the voyage - a voyage that made them 'coolies' as a labour category in their new land. India, their home country $(u r)$ or their own village/land (sontha ur), remains a potent memory; reproduced as oral narratives or living artefacts of belonging (such as the mango tree) or as religious rituals and practices from their own villages. Here, memory, the act of remembering itself, appears to have become an act of resistance and defiance, negotiating an identity against the (often) forced indenture and the inheritance of subjugation and marginalisation passed on to them.

In a reply to Amitav Ghosh (2011, October 1) about 'coolitude', Khal Torabully, author of the edited collection Coolitude: An Anthology of the Indian Labour Diaspora, wrote:

When I wrote Cale d'étoiles-coolitude, the founding book of the oceanic voyage of the coolies in 1989 (published in 1992), I wanted to pay homage to the "forgotten voices of the voyage", the coolies'. [...] I carved [the term 'coolitude') as the basis of a humanism of diversity born from the mosaic India migrating through indenture. I played with languages and archives, moved to silences of archives, sketched the centrality of the voyage of the coolie as a space of construction/deconstruction of identities, giving a primordial role to the ocean so as to move away from the "kala pani petrification". This ocean, I am convinced, should be explored again and again, as it is a space where diversities meet, clash and emerge in new configurations of humanities. I believe time has come to gather interest on this ocean, I believe the Atlantic has had its fair share of narratives and studies, and we have to come back to Sinbad's ocean, to re-discover it and allow articulation of other imaginaries in this matrix of globalization (with a different tinge!). (Torabully, qtd. in Ghosh, 2011, October 1).

For Torabully, 'coolitude' captures the trauma of the of sea voyage across the kala pani for the coolies. That journey was one of immense and terrifying loss—not just of their ' $u$ ' and 'sontha ur'; but also, of all the practices and cultural systems and ways of life and knowledge that made them who they were and made them what they were now becoming. It was not difficult to see why these kampungs in which they now resided in this squatter settlement area were named after famous Indian leaders like Mahatma Gandhi and Jawaharlal Nehru; possibly linked to the complex history of an imaginary of the homeland India-forged from the treacherous crossing of the black waters (kala pani) of the Indian Ocean-to recreate a home in the new homeland. While the word 'coolie' within the Malaysian context is dismissed as a highly pejorative term, my conversations with the Tamil labourers in the squatter settlements as well as of the HINDRAF mobilization rally of 2007, suggest that the 
power of this narrative is still salient, locating itself within a contemporary political landscape and Indian perceptions of identity, class and belonging.

As Carter and Torabully (2002, p. 144, p. 149) attest, "the coolie had to forge a 'composite identity', keeping his or her Indian identity yet absorbing other cultural influences creating a 'mosaic self in the adopted home." Through this form of narrative, I am also trying to find the orthographic form that can, to an extent, portray the long history of social displacement and the silenced presence of an imperial debris; to cast some sort of selective spotlight on the historical landscape of Malaya at those moments when capitalist and colonial mentalities contributed to the formation of the coolie as a matrix of power relations. As Balachandran (2011, p. 267) points out, by the late $19^{\text {th }}$ Century, the word 'coolie', used in relation to anyone performing labour for a wage or payment of any kind, had acquired "an almost formless malleability [...] lost all contextually shaped meanings [...] other than the most pejorative $[\ldots]$ the malleability of the term now appeared naturally to speak to the presumed malleability of the (non-) person it described, and to normalize coercive relations and institutions to stabilize her."

The word 'coolie' haunted me; and the way the Tamils used this term, always with the word 'al' (person), as 'coolie-al'. This second word 'al' remained like a ghost in the English lexicon. The work of Daniel Valentine provided considerable historical and visible contextualisation, giving me much freedom to focus on this word; and its historiography in the lives of Tamils themselves. The term 'coolie' (kuli in Tamil) refers to the type of payment for a job, primarily menial. Therefore, just using the word ' $k$ uli' by itself in Tamil does not present the person. As Daniel $(1992,2008)$ attests, literature covering the period in the $19^{\text {th }}$ Century and first half of the $20^{\text {th }}$ Century of colonial expansion and the plantation economy was mostly written in the colonisers' languages - and in the process, the person (al) was appropriated by the menial payment they received ( $k u l i)$, thereby making a 'coolie'. The term 'coolie' was no doubt used to refer to coolies emerging at that time from all over Asia. Interestingly, despite its usages across the world for more than two centuries to mean a person doing menial work, in Tamil the suffix 'al' never lost its place. It held its own, like a hidden hyphen: "that held kuli and al together and apart. The struggle of the coolie then has been the struggle to recover an identity that is not fractured, not alienated from place, skill, and a moral centre" (Daniel, 1992, p. 291).

What is to be gained by my seeking personhood, seeking the 'al'? In reflecting on this journey with identity, I have tried to combine a personal narrative with more analytic modes of writing. I grew up with a distinct sense of Tamil ethnicity inherited from my grandparents on both sides, who carried their own histories of displacement from Ceylon (now Sri Lanka) and settlement in Malaya. Many of their stories emphasised dealing with the present; and I grasped at the occasional nostalgic or wistful stories of their displacement from their homeland. Often, I would glimpse into these silences they kept; wrought by surviving in a new land; through a sudden burst of a song; or an incomplete narrative of their involvement in the Free India Movement in 1942 or the 1941 coolie revolt in Klang Valley.

It is a process that undoubtedly has its own uncertainties, as well as its critical moments of research. I have previously termed this process an "in betweenness of research" (Nadarajah, 2007, p. 129), attempting to balance the context, the culture, the intersubjectivity of the researcher and the researched: 
In a sense, then what is at stake is not simply the navigation and renegotiation of the ideologies of power, but rather a profound reflexive encounter with the ontological and epistemological coordinates of the social theoretical discourses that have underpinned the disciplinary terrain and political practice of Malaysia [... but] to align oneself within such an 'in-betweenness' geopolitical and 'neither/nor or both/and' place, complicated by these dense layers of interrelationships, while carrying out research on issues related to that very struggle is to also occupy a space of deeper scholarly understanding.

\section{Ocean as hyphen, and the island within: Where is the rest of the coolie?}

The ocean that I found in island studies brought me to Kamau Brathwaite and his ocean and tidalectics. As DeLoughrey (1998, p. 18) points out, Braithwaite's terminology of aquatic metaphors and tidalectics "facilitate a reterritorialization of post-colonial historiography. Tidalectics draw upon the movement of the water backwards and forwards as kind of a cyclic [...] motion, rather than linear."

DeLoughrey (2007, p. 2) draws attention to the ways in which European colonialism has "constructed the trope of the isolated island by mystifying the importance of the sea and the migrations across its expanse." DeLoughrey's (2007, p. 2) efforts to re-centre the ocean in island discourse deploy Kamau Brathwaite's theory of tidalectics as:

a methodological tool that foregrounds how a dynamic model of geography can elucidate island history and cultural production, providing the framework for exploring the complex and shifting entanglement between sea and land, diaspora and indigeneity, and routes and roots.

Braithwaite's tidalectics further captures the cyclical motion of tides, the centrality of water, and the specificity of the transoceanic voyage that lies at the centre of Torabully's (1996) coolitude construct. A reterritorialisation based on Torabully's notion of coolitude through the methodological tool of Braithwaite's tidalectics aptly captures/signifies movements and entanglements between the land, sea, diaspora and language. For Torabully, coolitude explains the trauma of the sea voyage across the kala pani. While Torabully mainly spoke of the majority of those who came from Bihar, Uttar Pradesh, and Bombay, his writing resonates for all who have experienced indentured labour and arduous journeys across the kala pani. The ocean is open to reinterpretation, a reconsideration of its roles in both the voluntary and involuntary movement of people as well as its repercussions in contemporary culture. From a subaltern position, as subjects of extreme exploitation, still searching for labour, this indentured Tamil labourer/coolie community embodies the material history of crossing the ocean to become an instrument for capital accumulation and investment.

' $A l$ ' (personhood) remains invisible, concealed in the seas as a colonial wound of history, a tidalectics between transoceanic migration, personhood and language. Stoler (2013) wonders if one should look not just at the colonial legacy but also at its imperial debris, its runs and the processes of its undoing, which continue to exert their influence today in a myriad of ways. How have empires in the past produced their subjects and maintained their power? Stoler's questions help uncover that which had been rendered invisible by the 
dominant operative term 'coolie' in the legacy bequeathed (and still simmering) by the schemes of indentured Indian labour. Stoler (2013, p. 6) too thinks that:

The challenge is directed more broadly at a deeper set of assumptions about the relationship between colonial pasts and colonial presents, the residues that abide and are revitalized - if in different working order today $[\ldots]$ their examination provides opportunities to unsettle well-worn formulations of imperial attributes, to consider an alternative vocabulary, and in so doing to redirect our questions.

Braithwaite's tidalectics enables movement into what he sees as an alter/native epistemology that challenges western colonialism and its linear and materialist biases. The uprooting of my own assumptions and opening of another line of inquiry through this process challenges such linear and materialist basis. I found myself opening into a relationality into the ways we might listen to one another; and in this the way, the ocean too spoke to us through these narratives. Is it possible that these transoceanic crossings carried the weight of these indentured labourers' histories, the 'al' lost in the seas as an invisible island-rooted in the ocean as a colonial wound of history, a 'tidalectics' between transoceanic migration, personhood, and language? As DeLoughrey (2007, p. 2) points out, "As a geopoetic model of history, Brathwaite images the ongoing and palpable heritage of 'submerged mothers' who cross the seas, 'coming from one continent/continuum, touching another, and then receding [...] from the island(s) into the perhaps creative chaos of the(ir) future' $(1999,34)$." In so many ways, this "inbetweenness of research engagement" and one's own genealogy at the complex intersection of multiple colonial histories draws one into the neither/nor, or both/and space - "moving through the fusion and synthesis, but also the rigidity and discord, contestations and interrogations that go hand-in-hand in such a position" (Nadarajah, 2007, p. 129). I build upon this intersubjectivity to destabilise the term 'coolie' to describe a lowly paid contractual labourer; and engage in the tidalectics between transoceanic migration, personhood and language to retell, through coolitude the story of the hidden hyphen 'al' that held the labourer and the personhood apart, but also together.

The coolie journey shows that, in the face of so many odds, there has been a journey of self-discovery, a deep cultural affair, affecting acceptance, negotiating the rule of law and equality irrespective of race, creed and background. It may be that the coolie as a selfconscious identity remains entangled with its transoceanic crossing - an imaginary island that continues to reassert itself against all efforts to keep this identity afloat and connected to its mainland. The ocean facilitates its metaphorical presence as an island of lost ancestral memories. Yet not entirely lost-kept alive through the oral stories, cultural and living artefacts, rituals and ceremonies and memories of those now left to renegotiate their lifeworlds on the mainland.

In his tribute to Kamau Braithwaite on his passing away on $4^{\text {th }}$ February 2020, Fred D’Aguiar (2020) said:

Kamau made the sea a reliquary for recovery of the past and a talisman for understanding the present. His sense of play in his portrait of light reflected off the sea and splashed, as it were, across a boy's bedroom wall confirms the print of a voice as not fixed in diction and syntax but liberated by the two. 
I could not agree more-Kamau Braithwaite made the ocean a reliquary for recovering the past; and in that, he has made it possible for us to understand the present. 'Coolie', no longer inevitably derogatory or inevitably grossly utilitarian, has been liberated, opened up to being understood as one part of a whole person, this island in the ocean. In 'coolie-al', we find a person intact-courageous and resilient and honourable. What new pattern of identity politics may thus emerge for the working-class Indian and challenge our understandings of transoceanic crossings, islands, and identity? Themes such as water and oceans, as liquid knowledge portals, can make visible (and conscious) a lexicon that enables a metaphorical presence of islands-in this case, as a tidalectic reframing of identity politics between transoceanic migration, personhood and language.

\section{The first narrative}

By 1940, the socioeconomic conditions for the labourers in Malaya's plantations had deteriorated further. Following the Great Depression of 1929-1933, thousands of Indians abruptly repatriated, and the remaining workforce suffered substantial wage cuts, which eventually culminated in workforce strikes. While there were immediate contributory factors which triggered the strikes, the major causative factors had long been present. The 1930s also witnessed the rise of Dravidian ideologies within labouring communities, and legislation specifically aimed at curbing the growing economic power of one group of Indian migrants, the Chettiar moneylenders. This was coupled with the visits of Indian nationalists (including Nehru), the failure of the Sastri Report (Sastri, 1937) to reveal labourers' actual working and living conditions, the growing organization among Indian workers, the rise of the Central Indian Association of Malaya and its direct links to the Indian Congress, and the abolition of the recruitment of Indian labour in 1938.

The so-called Klang Strike began on the $8^{\text {th }}$ April and lasted till the $17^{\text {th }}$ May 1941, affecting an area of more than 1500 square miles, stretching from Klang Valley to Sepang. Wilson (2006) contends that had the workers been better organised, with effective forms of communication to concentrations of estate labourers, the strike would have been panMalayan in scale and scope. The strikes were forcibly suppressed. Many of the workers were jailed for breaching contracts and refused to return to the estates after release, saying that they preferred to stay in jail, or even walk into the sea and be drowned.

By $15^{\text {th }}$ February 1942, the Japanese had occupied the whole of Malaya and taken over the government administration (Ramaswamy, 1988). The most devastating effect of Japanese occupation for many of these indentured workers from India in Malaysia was the forced recruitment of labourers to work on the infamous 'death railway' from Siam to Burma. Many rushed to join the Indian Independence League and the Indian National Army. While many claim that the labourers joined these movements to escape recruitment into horrendous work on the death railways in Siam, others (Ramasamy, 2006) contend that the labourers were drawn to the charismatic promise of democracy and human freedom espoused by Indian leaders such as Subhash Chandra Bose, Jawaharlal Nehru and Mohandas Gandhi. This struggle to retain an identity (South Indian), while pulling together a new place of belonging and attachment (Malaya), narrates an experience for this Indian immigrant community that goes far beyond that which has been formed through the ages by discourses of imperialism and race. If we deconstruct the subtexts underlying the discourse of subjugation and domination 
of the coolie experience and dislodge their deeply embedded discursive pillars, the story of this group of Indian immigrants takes on a new script.

Torabully's (1996) 'coolitude', that journey by sea, engrained within the coolie psyche a new imaginary landscape. This landscape represented the deconstructed memory of the atavistic homeland (Indianness as a set of values) and the reconstruction of a metaphorical family, possibly through the acceptance of a form of servitude. Coolitude explores "the concept of the ocean as a nodal moment of migration, a space for destruction of identity, yet also one of regeneration, when as aesthetics of migration was created" (Torabully, 1996, p. 17). "It is impossible to understand the essence of 'coolitude' without charting the coolies' voyages across the seas. That decisive experience, that coolie odyssey, left an indelible stamp on the imaginary landscape of coolitude" (Torabully, 1996, p. 13).

As one alternates between isolation and adoption, the distinction between voluntary and involuntary is sometimes blurred, to the point of disappearing completely. Questions of identity have been answered by the life that has been lived in the process of a 'coolitude' that traversed the seas and then the land. The coolie knows from experience that identity with a single root alone will not enable their survival, their ability to return home one day (if they can). This is poles apart from the agency required by the imagination, which is constantly replenishing itself by drawing on the complementary resources of their original atavistic homeland and the intensely experienced home-life they have made, under the girdle of colonial order. Already, the coolie's struggle has been one of recovering an identity that is not fractured, not subjugated, not controlled. Notions of agency are already evident as coolies resisted and tested the frames of colonial control, portraying the actions and counteractions of proletarians. "The docile body was not so docile when seen as an agent of own cultural identity, one that resided within and was an affirmation in many senses of the possession of something that could not be manipulated by colonial control" (Pillai, 2004, p. 164).

Set against this context, coolitude broadens the concept of the Indian abroad, the plantation labourer, the struggle to claim an impenetrable colonial space. The raw emotion of transition, and upheaval, of uncertainty and struggle and the creation of another identity beyond India reveal something special. This immigrant Indian set the stage for debates about the postcolonial nation, changing conceptions of postcolonial identity, migration and the search for the hyphen that held their personhood.

\section{The second narrative}

Professor Arasaratnam (1993) described the evolution of a "plantation-oriented culture" which he believed defined and described Indian marginalisation, and to a large extent circumscribed Indian working culture and socio-political aspirations. Many scholars believe that the HINDRAF (Hindu Rights Action Force) mobilization rally of 2007, which protested policies favouring ethnic Malaysians, and the subsequent 2008 election when the politically compliant Malaysian Indian Congress was all but eliminated as a political force, signified Indian determination to break free of this culture. Some might argue that the conciliatory gestures made by the current administration toward the Indian community, however limited, represent recognition of the shifting electoral and ethnic realities in Malaysia.

The Indian community in Malaysia constitutes about 6.8\% (2019) of Malaysia's population of approximately 32 million. According to Ratnam (1965), at the time of 
independence in 1957, Indians constituted $12 \%$ per cent of Malaya's population. Indian interests have been represented over the years by a succession of both national and local level institutions such as Malaysian Indian Congress (MIC), which represented the Indian constituency in the federal government; Yayasan Pemulihan Social (YPS); and more recently MITRA Malaysian Indian Transformation Unit (MITRA) under the Prime Minister's Department (established in 2008). The Indian working class continues to be associated with some of the most menial economic positions in the country: road sweepers, plantation workers, and labourers. Those recruited specifically to work as labourers in the colonial economy were also caught in a development which denied them opportunities and created an ongoing framework for postcolonial exclusion. Malaysian Indians striving for belonging are thrust forward as an imagined re-enmeshing of Tamil and Malay historicity, if not identities, of being historically authentic. Where is this heading? What will this bring? Indian community issues remain unresolved, simmering. As Wilford (2008) contends, the force of law is 'haunted' by the wake of its destruction as well as its inherent deconstructibility. But in the fragmentation of memory and experience wrought by state betrayals and the violence of displacement, a recognisable logic within, in this case, the Malaysian Indian working-class Tamil Hinduism has taken hold, in part as a political recourse, fuelled by a simmering restlessness.

The interviews I conducted with members of the squatter settlement community over a period of ten years were remarkably consistent. Little had changed over this time. Many felt that their grandparents and parents, who had come in as indentured labourers bonded by colonial control, now remain bonded by what they experience as Malaysia's inherently discriminatory policies. There was a growing sense of powerlessness and desolation amongst many of the residents, particularly the men aged between 20 and 35 . This squatter settlement, characterised by plank squatter houses, had housed primarily the lowest income group of Malaysia. Almost all residents in Kampung Gandhi and Kampung Nehru, where I was doing my fieldwork, worked as daily wage earners in small factories and businesses or as cleaners and road sweepers. Daily lives were riddled by domestic violence, alcoholism, crime, prostitution. Yet cultural events and family or neighbourhood celebrations and gatherings (often at the dilapidated coffee stalls scattered though the villages) were common, often jocular and inclusive of outsiders like me. Numbers in this squatter settlement grew after the 1960s as rubber and oil palm plantations and mining industries in rural towns slowed down or closed completely (Nadarajah, 2007). Many of these squatter communities came looking for work in the metropolitan areas, and many of them had lived in this area for well over 40 years. Records held by some of the NGOs working with these communities indicated that there were an estimated 30,000 people living around this area by the end of 1999 .

It is impossible to obtain accurate figures for the number of families and their backgrounds, as many of these houses and communities have metamorphosed in complex, unregulated ways over several decades. These communities were already in the process of being shifted to either temporary or recently constructed low-cost flats when I first began my fieldwork there in 2005. A complete shift was planned for completion by the end of 2007. The introduction of a 'zero squatter settlements' directive from the State was primarily underpinned by the implementation of development strategies in line with moving forward on Malaysia purported Wawasan 2020, Malaysia's then-development strategy for economic, political and social reforms. Wawasan 2020, translating to 'Vision 2020', was a set of nationwide reforms first introduced in Malaysia by Tun Dr. Mahathir Mohamad at a conference at 
the Malaysian Business Council on $28^{\text {th }}$ February 1991, which went on to replace the existing New Economic Policy which was coming to an end. These reforms espoused policies to be adopted by the government for transforming Malaysia into an industrial powerhouse capable of competing in the geopolitical region and internationally by the year 2020 .

Several academics and social commentators have remarked that this directive may have been prompted by a week of violent clashes in the area in early 2001. Wilson (2008, p. 441) posits that numerous stories in the media described the events as 'racial riots', 'communal clashes', or 'ethnic riots', while others emphasise economic frustrations and marginalisation, compounded by decrepit housing and rising crime rates. A visit to this area in late July 2008 indicated that almost all of the squatter communities had moved into new low-cost housing flats, and the squatter settlements had been demolished. It was getting harder to keep track of the original group of squatter settlement members I had begun a series of interviews withas many did not know the new whereabouts of the old neighbourhood or members of the same community. These flats have been constructed in and around the same area that the squatter settlements once stood, where I now continue my conversations and visits as well as participation in family and religious events.

It is apparent that, over six decades following independence, the interests of this stratum of Malaysian Indians remain unmet. Many remain as squatters or in dense, low-cost housing complexes, prey to exploitation and old and new forms of oppression. In 2015, the welfare arm of the Malaysian Indian Congress Yayasan Pemulihan Social (YPS) said about 40\% of Malaysian Indians were still at the bottom of the income ladder. That figure has changed little in the intervening years. Wilkins (2019) points out that this "established ethnic community predates independence, but institutionalized discrimination and social segregation have turned it into what one academic has described as 'a new underclass'." Wilkins (2019) adds that nearly half of the 2.6 million Indians in Malaysia are at the bottom of the income ladder, and according to the head of Yayasan Pemulihan Social (YPS), Professor K.S. Nathan of the National University of Malaysia, "urban poverty, inequality, undocumented Indians, and a lack of educational opportunities are among the issues that require serious attention." Nathan indicates that these problems arise due to the lack of opportunities, access, recognition and self-esteem.

\section{A conundrum of the lost hyphen: Then, now, and for how long?}

Even after decades of suppression, previously under British rule and then under the modern state and capitalist development, much remains the same for many in the Indian community, despite the sustained performances of political, socio-economic and cultural resistance. A Malaysian Indian Blueprint (MIB) set up by the federal government in 2017 has done little to tackle issues plaguing Indians, especially in the Bottom 40 (B40) group, who make up $38.71 \%$ of the population. T20, M40, and B40 are terms used broadly in Malaysia to classify household incomes; more specifically as definitions of upper class (T20), middle class (M40), and lower class (B40), dividing Malaysian household incomes into percentages. Another ontological divide rooted in coloniality, maybe. A new and emerging image, that associated with crime and gangsterism, has begun to take hold of these already much-maligned communities. As described by Devi (2018, in the online journal Fountainhead): 
For Tamil schoolteacher S. Malar, the education system offers no real hope. She says her pupils must also work at part-time jobs to make ends meet at home. "What real hope is there when discrimination is everywhere you turn," says Malar who has been in Tamil schools for 40 years. "After 61 years of independence there has been no significant upward mobility in the Indian community, most of whom are Tamils. We Indians are like refugees-poor, hopeless, can't find jobs, can't feed the family. So, being part of a gang works.

The individual stories of each generation in these families are often influenced by a range of factors. But one can see the impact of the larger political changes mirrored in the trajectories of their lives. Unsurprisingly, the word 'coolie' in my own meetings with the second-generation families of the indentured labourers emerged most defiantly and powerfully, as if to reclaim an identity born out of the trauma suffered from the time their forefathers set foot on the ships that were to transport them to new lands of food and security. I am reminded of what Carter and Torabully (2001, p. 161) point out:

Contradictions were abundant in colonial societies - for instance - the perceptions of the coolie - the newcomer whose image oscillated between the docile agricultural labourer and the vicious, dirty, rebellious, immature subhuman malingerer. This is also part of the coolie's memory. In this respect, the indentured labourer was never fully recognised as a citizen of the countries where they had settled, sometimes for several generations.

For some commentators, the HINDRAF rally has highlighted the slow erosion of what many had taken for granted, the plural nature of Malaysian society, and it pointed to a growing divide between rich and poor. It also highlighted the growing divide between the rich and poor Malaysian Indians especially. Of course, struggles over the political future of Malaysia have a long way to go. The desire for a secure sense of belonging has not diminished, particularly for those who have reason to fear the uncertainties of a globalising world. As Akhilandam Patti, one of the older women interviewed at the new high-rise, low-cost flats, who had lived for 40 years in the squatter settlement, said "Where can I go? I came to Malaysia when I was four years old. We never went back to India. Malaysia contains everything I have known. This is my ur, my sontha ur now."

Rallies like HINDRAF provided a space for Malaysian Indian unity, but the heavyhanded response from the Malaysian authorities has ensured that the movement remains suppressed and increasingly divided. While the work of contemporary playwrights like K.S. Maniam and local academics like Shanthini Pillai (2004, 2006, 2007) and P. Ramasamy (1992, 2006) attempt to move the discourses of the Malaysian Indian coolie history out of subalternity, much remains a hostage of colonial scripts. "The question that needs to be asked is what are some possible ways for the present day Malaysian Indian community to responsibly integrate the patterns of its coolie past into this reterritorialized space of globalised identity?" (Pillai, 2007, p. 168)

Like Pillai (2004), I too contend that, for too long, historical texts, particularly of the coolie experience (in this case of the Tamil coolie of Malaya), have primarily reflected the tones and inflections of imperial voices and are "in many senses the scripts of empire that 
staged the drama of the encounter between imperial control and its subordinate labour force" (Pillai, 2007, p. 2). As Daniel et al. (1992, p. 290) further attest:

A coolie identity is as much the product of self-definition as it is of the construction of a category by those who did not belong to it. But the identity we have constructed has been drawn mainly from the latter and not the former. The resulting picture has been one of 'coolie as victim'. The imagery is almost overdone: flotsam and jetsam, being cast adrift, a bricole, demoralised, debased and dejected.

Through these narratives, I am attempting to reveal the historical continuities of the indentured labourers - providing the argumentative and contextual lens for the ontological and identity-based struggles experienced by the coolies. The part-metaphorical, part-physical, part-methodological conception of 'tidalectics' provides a new space in my further attempt to reterritorialise the post-colonial historiography of the coolie people, certainly one that was not passive or cowardly. The colonial system of representation presented passivity, a façade that was upheld. The resulting picture is one of "coolie as victim" (Daniel, 1992, p. 290): "The image is almost overdone; flotsam and jetsam, being cast adrift, a bricole, demoralised, debased and dejected."

Where to from here? Back to the ocean? What was lost in the journey across?

\section{Conclusion}

To many of the men and women in the squatter settlement, the term 'coolie' remains a form of self-identity, the essence of a personhood that the coolies themselves have anchored in the kala pani they crossed. Yet it has lived on, in the stories, in their struggles, in the passing of the mango tree sapling. This paper attempts to make visible the 'al' as an identity for people who lived on lands that never became their own. The ocean remains entrenched in their stories. And the journey across the ocean continues to play a part in these narratives. The ocean - at this interface of transoceanic crossings, mainlands and settlements - continues to craft the dramatic and escalating questions of belonging and unbelonging. At the same time, the ocean holds the invisible character of resilience and identity, challenging our understandings of what it means for those who continue to live at this intersection of ocean, transoceanic crossing, land and an imaginary island.

The paper locates the 'al' in this intersection; locating through the narratives of the Tamil settlement community and the historical moments of resistance; whilst drawing upon Daniel and Torabully's work, Braithwaite's tidalectics, and the author's own questions of the inbetweenness of research locations. In this, the paper reterritorialises the Tamil 'kuli-al'. Out of the exile from country $(u r)$, land (sontha $u r$ ) and reconnection to the ocean (kadal), the "kulial hones their voice to the pressures of marginalisation and deep struggles in their current nation place. And in the rhythm of the ocean washing over their island of recall-liberated by the union of the two-where centuries of oppression have failed to colonise their defiant, rebellious spirit. There is much to learn from this kuli-al, their assertions of power, affairs with identity and belonging, and responses to deep social inequalities in their homeland.

The ocean haunts the marginalised Tamils in many ways. The mango tree narrative is one of many stories that draws upon their transoceanic journey. In this article, I have extended 
and built upon the tidalectics between these transoceanic journeys, the reiteration of the term 'al' to 'coolie' and its personhood as gestures that rethink the idea of 'islands' (imaginary or visible or invisible) as premises of memory, metaphors, and colonial debris. These islands are made visible only through these squatter settlers' memories, songs, testimonies, metaphors, and artefacts. Even those such as the seed of the mango tree. Ultimately, the 'island' advances a legacy toward a postcolonial dream, opens it to our contemporary existence. It engages with not only the human and non-human aspects, but also the metaphorical, politico-ontological imaginaries of oceanic space, islands and a resilient personhood. In this way, we also may open up a research agenda that can combine island studies with critical decolonial understandings of oceanic space and transoceanic lifeworlds to evolve an island studies more open to the Global South.

Kannamma's grandmother would be pleased to know that the mangoes that came across the ocean with her have gone on to produce oceans of mangoes. This grandmother's journey is not lost; and this invisible island on the ocean that beckons to Kannamma now and then, awash with mangoes.

\section{References}

Balachandran, G. (2011). Making Coolies,(Un) making Workers: "Globalizing” Labour in the Late-19th and Early-20th Centuries. Journal of Historical Sociology, 24(3), 266-296. https://doi.org/10.1111/j.1467-6443.2011.01398.x

Breman, J, (1989). Taming the coolie beast. Oxford University Press.

Bunnell, T. (2004). Malaysia, modernity and the multimedia super corridor: A critical geography of intelligent landscapes. Routledge. https://doi.org/10.4324/9780203647363

Carter, M., \& Torabully, K. (2002). Coolitude: An Anthology of the Indian Labour Diaspora. Anthem. https://doi.org/10.7135/upo9781843313670

Cooper, F., \& Stoler, A. L. (Eds.) (1997). Tensions of empire: Colonial cultures in a bourgeois world. University of California Press. https://doi.org/10.1525/9780520918085

Daniel, V. E. (1984). Fluid signs: Being a person the Tamil way. University of California Press. https://doi.org/10.4324/9781315827889

Daniel, V. E., Bernstein, H., \& Brass, T. (Eds.) (1992). Plantation, peasants and proletarians in colonial Asia. Frank Cass and Co. https://doi.org/10.1017/s0010417500018594

Daniel, V. E. (1993) Tea talk: Violent measures in the discursive practices of Sri Lanka's Estate Tamils. Comparative Studies in Society and History, 35(3), 568-600. https://doi.org/10.1177/006996670103500307

Daniel, V. E. (2001). Charred lullabies: Chapters in an anthropography of violence. Princeton University Press.

Daniel, V. E. (2008). The coolie. Cultural Anthropology, 23(2), 254-278.

Das, V. (2007). Life and words: Violence and the descent into the ordinary. University of California Press. Das, M. (2010). A leaf in his ear: Collected poems. Peepal Tree Press.

D’Aguiar, F. (2020, February 20). 'A towering figure': Tribute to Kamau Brathwaite (19302020). Wasafiri International Contemporary Writinghttps://www.wasafiri.org/article/a-. towering-figure-tribute-to-kamau-brathwaite-1930-2020/

Delanty, G. (2003). Community. Routledge.

DeLoughrey, E. M. (1998). Tidalectics: Charting the space/time of Caribbean waters. SPAN, 47, 18-38. 
DeLoughrey, E. M. (2007). Routes and roots: Navigating Caribbean and Pacific island literatures. University of Hawaii Press. https://doi.org/10.1515/9780824864187

Ethan, G. R. W. (2017). Charting the sea in Caribbean poetry: Kamau Brathwaite, Derek Walcott, Dionne Brand, Alphaeus Norman, Verna Penn Moll, and Richard Georges. Doctoral thesis (PhD). University of Sussex.

Ghosh, A. (2011, October 1). Coolitude and Khal Torabully. https://amitavghosh.com/blog/?p=1210

Grydehoj, A. (2017). A future of island studies. Island Studies Journal, 12(1), 3-16.

Haridas, A., \& Dhandayudham R. (Eds.) (1981). The interior landscape of the heart: Tamil poetry from Malaysia and Singapore. P.Lal.

Jain, P. C. (1988). Exploitation and reproduction of migrant Indian labour in colonial Guyana and Malaysia. Journal of Contemporary Asia, 18(2), 189-206. https://doi.org/10.1080/00472338880000141

Klein, A. (2015). Stretching the bounds: Women's experience of indenture in Peggy Mohan's Jahajin. South Asian Review, 36(3), 65-79. https://doi.org/10.1080/02759527.2015.11933034

Kuecker, G., Mulligan, M., \& Nadarajah, Y. (2011). Turning to community in times of crisis: Globally derived insights on local community formation. Community Development Journal, 46(2), 245-264. https://doi.org/10.1093/cdj/bsq002

Mohammed, P. (2002). Crossing the Black Water: From India to Trinidad, 1845-1917. In P. Mohammed (Ed.), Gender negotiations among Indians in Trinidad 1917-1947 (pp. 1753). Palgrave Macmillan. https://doi.org/10.1057/9781403914163 2

Mulligan, M., \& Nadarajah, Y. (2008). Working on the sustainability of local communities with a 'community-engaged' research methodology. Local Environment, 13(2), 81-94. https://doi.org/10.1080/13549830701581911

Nagarajan, S. (2008). Indian in Malaysia; Towards vision 2020. In K. Kesavapany, A. Mani, \& P. Ramasamy (Eds.), Rising India and Indian communities in East Asia (pp. 375-398). Institute of Southeast Asian Studies. https://doi.org/10.1355/9789812308009

Nadarajah, Y. (2007). The outsider within-commencing fieldwork in the Kuala Lumpur/Petaling Jaya Corridor, Malaysia. International Journal of Asia-Pacific Studies, 3(2), 109-132.

Nadarajah, Y. (2007). Life under the freeway in Malaysia: Community resilience amidst modernisation in contemporary Malaysia. Local-Global, 4, 70-81.

Nadarajah, Y., \& Grydehoj, A. (2016). Island studies as a decolonial project. Island Studies Journal, 11(2), 437-446.

Pillai, S. (2004). Reclaiming space on a transforming plantocratic chequerboard: Pierre Boulle's sacrilege in Malaya. Journal of Colonialism and Colonial History, 5(1). https://doi.org/10.1353/cch.2004.0036

Pillai, S. (2007). Integrating patterns of a coolie past: Literature and the figuring contemporary Malaysian identity. In T. S. M. Lee Sukim \& L. K. Siong (Eds.), Border crossings: Moving between language and cultural frameworks. Pelanduk.

Pillai, S. (2008). Reterritorialising literary studies: Deconstructing the empire of scripts. The South East Asian Language Studies Journal of Indonesia, 14(3).

Potts, L. (1990). The world labour market: A history of migration. Zed Books.

Ramasamy, R. (1984). Caste consciousness among Indian Tamils in Malaysia. Pelanduk. 
Ramasamy, P. (1992). Labour control and labour resistance in the plantations of colonial Malaya. In D. E. Valentine, H. Bernstien, \& T. Brass (Eds.) Plantation, Peasants and Proletarians in Colonial Asia. Frank Cass and Co. https://doi.org/10.4324/9781315827889-4

Ramaswamy, S. (1993). En/gendering language: The poetics of Tamil identity. Comparative Studies in Society and History, 35(4), 683-725. https://doi.org/10.1017/s0010417500018673

Ramasamy, P. (2006). Socio-economic transformation of Malaysian Indian plantation workers. In K. Kesavapany, K. A. Mani, \& P. Ramasamy (Eds.), Indian Communities in South East Asia. Institute of South East Asian Studies. https://doi.org/10.1355/9789812308009

Ramasamy, P. (2000). Indian War Memory in Malaysia and Singapore. In P. L. P. Huen \& D. Wong (Eds.), War and Memory in Malaysia and Singapore. Institute of South East Asian Studies. https://doi.org/10.2307/j.ctv1nthp3.15

Ramasamy, R. (1988). Sojourners to citizens: Sri Lankan Tamils in Malaysia, 1885-1965. R. Rajakrishnan.

Sandhu, K. S. (1993). The coming of the Indian to Malaysia. In K. S. Sandhu \& A. Mani (Eds.), Indian Communities in South East Asia. Institute of South East Asian Studies.

Sanusi, N. A., \& Ghazali, N. A. (2014). The creation of Bangsa Malaysia: Towards vision 2020 challenges. Proceeding of Persidangan Kebangsaan Ekonomi Malaysia ke-9 (PERKEM ke-9), "Urus Tadbir Ekonomi yang Adil: Ke Arah Ekonomi Perpendapatan Tinggi”, Kuala Terengganu, Terengganu, 17-19. https://doi.org/10.21315/km2020.38.s1.7

Sastri, S. V. S. (1937). Report on the conditions of Indian labour in Malaya. Government of India Press.

Savory, E. (2020, February 24). 'A Towering Figure': Tribute to Kamau Brathwaite (19302020). Wasafiri. https://www.wasafiri.org/article/a-towering-figure-tribute-tokamau-brathwaite-1930-2020/

Stoler, A. (2013). Introduction: 'The rot remains': From ruins to ruination. In A. Stoler (Ed.), Imperial debris: On ruins and ruination. Duke University Press. https://doi.org/10.1215/9780822395850-001

Torabully, K. (1996). The coolies' odyssey. UNESCO Courier, 49(10), 13-16.

Wilford, A. (2002). Weapons of the meek: Ecstatic ritualism and strategic ecumenism among Tamil Hindus in Malaysia. Identities: Global Studies in Culture and Power, 9(2), 247-280. https://doi.org/10.1080/10702890212203

Wilford, A. (2008). The Indian uprising and the haunting of justice in Malaysia. Lecture Series 2008-2009. Centre for South East Asian Studies, Department of Anthropology, Cornell University.

Wilford, A. (2006). Cage of freedom: Tamil identity and the ethnic fetish in Malaysia. University of Michigan Press. https://doi.org/10.3998/mpub.171840

Wilford, A. (2006). The 'already surmounted' yet 'secretly familiar": Malaysian identity as symptom. Cultural Anthropology, 21(1), 31-59. https://doi.org/10.1525/can.2006.21.1.31

Wilkins, A. (2019). Malaysia's Indians face growing racial hostility. Asia Times. https://asiatimes.com/2019/06/malaysias-indians-face-growing-racial-hostility/ 